\title{
DIGLOSIA
}

Volume 2, Nomor 1 (Februari 2019)

p-ISSN 2615-725X (Print)

Halaman 1-14

e-ISSN 2615-8655 (Online)

\section{TIPE TUTURAN REMAJA PEREMPUAN YATIM DALAM INTERAKSI SEHARI-HARI: KAJIAN PRAGMATIK}

\author{
Nur Ainin ${ }^{1}$, Alfian Rokhmansyah ${ }^{2, *}$, Purwanti $^{3}$ \\ ${ }^{1}$ Program Studi Sastra Indonesia, Fakultas Ilmu Budaya, Universitas Mulawarman \\ ${ }^{2,3}$ Universitas Mulawarman \\ ${ }^{1}$ Pos-el: nainin961@gmail.com \\ 2,* Pos-el korespondensi: alfian.rokhmansyah@gmail.com \\ ${ }^{3}$ Pos-el: purwanti.030991@gmail.com
}

\begin{abstract}
This study aims to determine the type of speech used by an orphaned teenager in daily communication. This research includes field research in the form of case studies with qualitative approaches and presented descriptively. The main data of the study are speeches in the activities of everyday speech acts. The data source is a 21-year-old orphaned teenager. The results showed that the type of speech used, namely the declarative, representative, expressive, directive, and commissive type. While the dominant sentence form is used, namely direct and literal sentences.
\end{abstract}

Keywords: type of speech, teenage orphaned girl, pragmatic

\begin{abstract}
ABSTRAK
Penelitian ini bertujuan untuk mengetahui tipe tuturan yang digunakan oleh seorang remaja perempuan yatim dalam komunikasi sehari-hari. Penelitian ini termasuk penelitian lapangan berbentuk studi kasus dengan pendekatan kualitatif dan dipaparkan secara deskriptif. Data utama penelitian adalah tuturan dalam kegiatan tindak tutur sehari-hari. Adapun sumber data adalah seorang remaja perempuan yatim berusia 21 tahun. Hasil penelitian menunjukkan bahwa tipe tuturan yang digunakan, yaitu tipe deklaratif, representatif, ekspresif, direktif, dan komisif. Sedangkan bentuk kalimat yang dominan digunakan, yaitu kalimat langsung dan literal.
\end{abstract}

Kata Kunci: tipe tuturan, remaja perempuan yatim, pragmatik

\section{A. PENDAHULUAN}

Tindak tutur yang dilakukan oleh seseorang umumnya dipengaruhi oleh pikiran, perasaan/emosi, maupun situasi, baik dari sisi internal maupun eksternal si penutur. Menurut Chaer (2010:27), tindak tutur adalah tuturan dari seseorang yang bersifat psikologis dan makna yang terkandung sesuai dengan tindakan dalam tuturan tersebut. Berpikir dan berbahasa merupakan dua aktivitas yang saling melengkapi dan terjadi dalam kurun waktu relatif bersamaan (Ali \& Asrori, 2016:126). Bahasa dapat dikatakan sebagai alat untuk berpikir. Jika dianalogikan, maka kegiatan berpikir adalah pistol, sedangkan bahasa 
adalah pelurunya. Oleh sebab itu, kemampuan berpikir seseorang dapat dilihat dari bahasa yang digunakan. Seseorang yang dapat mengontrol emosi akan lebih stabil dalam penggunaan bahasa, sebaliknya jika kondisi emosi seseorang masih labil maka bahasa yang digunakan juga akan relatif berubah-ubah. Pengontrolan emosi akan memengaruhi penggunaan bahasa yang lebih stabil. Akan tetapi, jika emosi tidak dapat dikontrol dengan baik, maka penggunaan bahasa akan lebih tidak stabil.

Remaja merupakan bagian rentang usia pada manusia yang identik dengan kondisi labil, baik secara emosi maupun pikiran. Ketika seorang remaja merasa senang, maka akan lebih mudah bahagia dan ketika sedih akan lebih mudah depresi. Kondisi inilah yang umumnya membuat seorang remaja terkenal dengan gaya berbahasa kurang sopan atau menggebugebu. Selain dipengaruhi oleh faktor internal, penggunaan bahasa pada remaja juga dapat dipengaruhi oleh kondisi eksternal yang kemungkinan memicu munculnya dampak-dampak internal. Salah satu contohnya adalah remaja yatim.

Usia remaja yang masih dalam pencarian jati diri, kemudian harus kehilangan salah satu sosok dalam kehidupannya, kemungkinan akan memicu perubahan dalam kondisi psikologis dan emosionalnya. Hal ini juga dapat perpengaruh pada pemakaian bahasanya dalam bertindak tutur. Atas dasar tersebut, penelitian ini menggunakan objek penelitian seorang remaja perempuan yatim. Remaja tersebut saat itu berusia 17 tahun ketika ayahnya meninggal. Ketika ayahnya meninggal, remaja tersebut tidak sedikit pun menangis untuk meluapkan kesedihan. Remaja tersebut lebih memikirkan perannya sebagai anak sulung yang harus menguatkan ibu dan adik laki-lakinya. Oleh karena itu, remaja tersebut menahan emosinya agar terlihat lebih kuat dengan tidak menangis.
Salah satu cara berbahasa remaja perempuan yatim tersebut terlihat saat sedang meminta minum dalam kegiatan latihan gabungan kelompok relawan. Jenis tuturan yang digunakan saat itu adalah kalimat langsung yang singkat dan literal, walaupun lawan tutur berusia lebih tua darinya. Selain itu, remaja perempuan yatim tersebut juga tetap dalam posisi berdiri ketika bertutur, sedangkan lawan tutur sedang duduk melingkar bersama teman-temannya. Jika dilihat dari sudut pandang pragmatik, maka tuturan Pak, minta minum! yang dituturkan remaja tersebut kurang sopan. Hal ini merujuk pada pendapat Chaer (2010:19) bahwa semakin panjang kalimat dan semakin tidak langsung maksud yang terdapat dalam kalimat, maka semakin sopan suatu tuturan. Oleh karena itu, seharusnya remaja tersebut mendahului tuturannya dengan kata permisi. Selain itu, ketika bertutur seharusnya remaja tersebut dalam keadaan duduk, sebagaimana yang dijelaskan Martadillah (2007:177) bahwa sikap dan posisi badan saat bertutur harus sama antara penutur dengan lawan tutur.

Cara berbahasa remaja tersebut dapat disebabkan karena beberapa faktor, seperti keluarga, lingkungan sosial, maupun situasi yang menyertai tuturan. Keluarga sebagai lingkungan pertama tempat belajar anak dapat menjadi pengaruh paling besar. Pengaruh tersebut dapat berasal dari didikan, kelekatan antara anak dan orang tua, posisi dalam keluarga, maupun kasih sayang yang diterima oleh anak. Lingkungan sosial dapat memberi pengaruh dari pergaulan, kedekatan dengan teman sebaya, maupun permasalahan-permasalahan yang pernah dihadapi. Sedangkan situasi yang menyertai tuturan dapat berupa maksud atau tujuan tuturan, kedekatan antaranggota tutur, maupun latar pengetahuan. Oleh sebab itu, satu maksud yang akan disampaikan dapat menjadi beragam bentuk tuturan sesuai dengan pribadi penuturnya. Begitu pula maksud 
yang diterima, setiap lawan tutur dapat membuat beragam pemaknaan sesuai dengan latar pengetahuan yang dimiliki.

Berdasarkan fenomena yang sebagaimana telah diungkapkan tersebut, maka penelitian ini bertujuan untuk mengungkap tipe tuturan yang digunakan seorang remaja perempuan yatim dalam komunikasi sehari-hari.

\section{B. LANDASAN TEORI}

\section{Pragmatik}

Dalam proses pemerolehan bahasa, Dardjowidjojo (2014:244) menjelaskan bahwa pragmatik merupakan proses pemerolehan kelayakan bahasa dalam tindak tutur. Yule (2014:5) mengungkapkan bahwa pragmatik adalah studi tentang hubungan antara bentukbentuk linguistik dengan penggunaannya. Hal serupa juga dijelaskan oleh Leech (2015:8) bahwa pragmatik adalah studi tentang makna dalam hubungannya dengan situasi ujar (speech situations). Maka dapat disederhanakan bahwa pragmatik adalah ilmu yang mempelajari makna bahasa sesuai dengan konteks yang menyertainya.

\section{Tindak Tutur}

Tindak tutur menurut Yule (2014:82) adalah tindakan-tindakan yang ditampilkan lewat tuturan. Sedangkan menurut Chaer (2010:27) tindak tutur adalah tuturan dari seseorang yang bersifat psikologis dan makna yang terkandung sesuai dengan tindakan dalam tuturan tersebut. Di dalam tindak tutur, tuturan atau kalimat memiliki dua sifat yaitu konstatif dan performatif. Menurut Austin (melalui Chaer, 2010:27) tuturan konstatif adalah tuturan yang dapat dicari kebenarannya karena hanya berbentuk kalimat berita. Sedangkan tuturan performatif adalah tuturan yang tidak mengandung nilai salah atau benar karena tidak hanya bertujuan mengatakan sesuatu, namun juga menyatakan perbuatan atau tindakan.
Austin (melalui Chaer, 2010:27-28) membagi tindak tutur yang menggunakan tuturan performatif menjadi tiga tindakan yang berbeda, yaitu tindak lokusi, tindak ilokusi, dan tidak perlokusi. Wijana (melalui Nadar 2013:15) menjelaskan tindak lokusi sebagai tindakan untuk menyatakan sesuatu (an act of saying something), tindak ilokusi sebagai tindakan untuk melakukan sesuatu (an act of doing something), dan tindak perlokusi sebagai tindakan untuk memengaruhi orang lain (an act of affecting someone). Tindak lokusi dapat disebut juga sebagai kalimat konstatif karena sifat tuturannya yang hanya bersifat menyatakan sesuatu. Sedangkan tindak ilokusi saling berkaitan dengan tindak perlokusi.

\section{Aspek Tuturan}

Menurut Leech (2015:19-20) terdapat lima aspek dalam situasi ujar, yaitu:

a. penutur dan lawan tutur: orang yang menyapa disebut penutur, orang yang disapa disebut petutur, sedangkan orang yang menerima dan menafsirkan pesan disebut penerima. Penerima bisa merupakan orang ketiga yang kebetulan lewat dan mendengar pesan dari penutur, namun hal tersebut tidak bisa mengubah penerima menjadi petutur karena orang ketiga bukan sasaran tuturan;

b. konteks, yaitu segala hal yang berhubungan dengan lingkungan fisik dan lingkungan sosial suatu tuturan. Dapat pula diartikan sebagai latar belakang pengetahuan anggota tutur sehingga dapat membantu lawan tutur dalam menafsirkan makna tuturan;

c. tujuan tutur adalah maksud atau motivasi (keinginan) penutur dalam menyampaikan suatu tuturan kepada petutur;

d. tuturan sebagai tindak tutur, tuturan digunakan untuk menghasilkan performasi-performasi atau aksi sesuai 
dengan maksud pada situasi dan waktu saat itu; serta

e. tuturan sebagai produk tindak verbal, selain tuturan sebagai suatu bentuk tindak tutur, tuturan juga merupakan produk dari tindak tutur yang berupa rangkaian kata-kata.

\section{Klasifikasi Tindak Tutur}

Sesuai dengan tindak ilokusi dari suatu tuturan, maka Yule (2014:93) mengklasifikasikan tindak tutur menjadi lima, yaitu deklaratif, representatif, ekspresif, direktif, dan komisif.

a. Deklaratif, yaitu jenis tindakan yang mengubah suatu keadaan melalui tuturan. Dalam hal ini, penutur harus memiliki peran institusional dan konteks khusus. Contoh, seorang bos yang bertutur kepada bawahan "Anda dipecat".

b. Representatif, yaitu tindak tutur yang menyatakan apa yang diyakini penutur. Misal, pernyataan suatu fakta, kesimpulan, dan pendeskripsian.

c. Ekspresif, yaitu tindak tutur menyatakan sesuatu yang dirasakan secara psikologis oleh penutur. Misal: kegembiraan, kesedihan, kebencian, kegundahan, dsb.

d. Direktif, yaitu tindak tutur yang digunakan penutur untuk menyuruh lawan tutur melakukan sesuatu. Misal: perintah, permohonan, pemesanan, pemberian saran, dan bentuk kalimat berupa positif dan negatif.

e. Komisif, yaitu tindak tutur yang membuat penutur terikat untuk melakukan suatu tindakan di masa mendatang. Misal: janji, ancaman, penolakan, dsb.

Selain itu, menurut Wijana dan Parker sesuai dengan bentuk kalimat atau tuturannya, tindak tutur dapat berbentuk langsung dan tidak langsung. Tindak tutur langsung adalah tindak tutur yang bentuk kalimatnya sesuai dengan makna sintaktisnya sehingga tuturannya sesuai dengan modus kalimat. Sedangkan tindak tutur tidak langsung adalah bentuk tuturan yang berbeda dengan modus kalimat, sehingga maksud dari tindak tutur tersebut tergantung pada konteksnya (Nadar, 2013:17-18).

Dilihat dari kata-kata yang menyusunnya, Wijana dan Parker membedakan tindak tutur menjadi literal dan tidak literal. Tindak tutur literal adalah tindak tutur yang maksud dan makna katakata penyusunnya sama. Sedangkan tindak tutur tidak literal adalah tindak tutur yang maksud dengan makna kata-kata penyusunnya saling berlawanan. Dengan begitu, secara ringkas Wijana dan Parker mengklasifikasikan tindak tutur menjadi empat (Nadar, 2013:20-21).

(1) Tindak tutur literal dan langsung, yaitu tindak tutur yang memiliki maksud sama dengan makna kalimat serta tuturannya sesuai dengan modus kalimatnya. Contoh ketika seorang dokter gigi yang bertutur kepada pasiennya, "Coba buka mulutnya lebar-lebar. Saya akan melihat tenggorokannya."

(2) Tindak tutur tidak literal dan langsung, yaitu tindak tutur yang memiliki maksud lain atau berlawanan dengan makna kalimat namun tuturannya sesuai dengan modus kalimatnya. Contoh ketika seorang mahasiswa Sastra Inggris yang tidak memiliki kemampuan berbahasa Inggris, "Beruntung aku diterima di Sastra Inggris, nilaiku jadi C semua."

(3) Tindak tutur literal dan tidak langsung, yaitu tindak tutur yang memiliki maksud sama dengan makna kalimat namun tuturannya berbeda dari modus kalimatnya. Contoh ketika seseorang sedang mencari tempat duduk di kantin, "Permisi, bisa geser sedikit?"

(4) Tindak tutur tidak literal dan tidak langsung, yaitu tindak tutur yang memiliki maksud lain atau berlawanan dengan makna kalimat 
serta tuturannya berbeda dari modus kalimatnya. Contoh ketika seorang kakak yang menegur adiknya karena asyik bermain playstation padahal esok hari ada jadwal ulangan, "Lanjutin aja terus main PS-nya, Matematika gampang aja kok."

Pengelompokan tersebut merupakan hasil dari peran aspek-aspek tutur. Selain itu, keadaan yang turut menyertai suatu tuturan (peristiwa tutur) juga turut menentukan maksud dari suatu tuturan.

\section{Yatim}

Yatim berasal dari kata ya-ta-ma yang mempunyai persamaan dengan kata al-fard atau al-infirad yang berarti 'kesendirian'. Maka yatim adalah seorang anak yang ditinggal mati ayahnya ketika belum dewasa (Al-Mahfani, 2009:2). Al-Laits membuat batasan yatim hingga usia baligh. Usia balig yang dimaksud di sini adalah ketika seseorang telah dewasa dan mandiri. Maksudnya, ketika intelektual dan emosi seseorang telah sejalan dengan perkembangan fisik (Al-Mahfani, 2009:4-7).

Dengan segala kondisi psikologi remaja yang telah dijelaskan sebelumnya, maka remaja yang kehilangan salah satu atau kedua orang tuanya masih disebut yatim. Menurut Napitupulu (2009:23) remaja yatim adalah remaja yang sudah tidak memiliki salah satu atau kedua orang tua untuk mengasuh karena berbagai alasan. Kondisi tersebut menurut Hurlock (melalui Napitupulu (2009:26) dapat menyebabkan perkembangan kepribadian remaja yatim kurang optimal. Biasanya, remaja akan meniru hal-hal yang diperbuat orang tuanya. Ketika orang tua tiada, maka seorang remaja akan kehilangan kerangka rujukan dan model positif yang berpengaruh pada rasa percaya diri (Napitupulu, 2009:236).

\section{METODE PENELITIAN}

Penelitian ini merupakan penelitian lapangan dengan korpus data berupa teks lisan, yaitu tindak tutur. Selain itu, jenis penelitian ini bersifat studi kasus sehingga hanya menggunakan satu objek penelitian. Dengan begitu, data hanya berasal dari satu sumber dan bersifat apa adanya, sesuai konteks yang menyertai tuturan. Penelitian ini menggunakan pendekatan kualitatif dengan pemaparan secara deskriptif untuk menjelaskan bentuk tuturan objek penelitian saat berinteraksi. Adapun sumber data penelitian ini adalah seorang remaja perempuan yatim yang sejak penelitian ini dimulai telah berusia 21 tahun. Remaja tersebut berusia 17 tahun ketika ayahnya meninggal. Sedangkan data penelitian ini, yaitu tuturan yang digunakan dalam interaksi sehari-hari.

Penelitian ini menggunakan teknik pengumpulan data berupa teknik libat cakap dan teknik simak bebas libat cakap. Teknik tersebut dikombinasikan dengan teknik sadap dan catatan lapangan. data yang telah diperoleh selanjutnya dianalisis menggunakan teknik analisis interaktif yang terdiri dari tiga komponen, yaitu reduksi data, sajian data, dan penarikan simpulan.

\section{HASIL DAN PEMBAHASAN}

Hasil penelitian menunjukkan bahwa ditemukan lima tipe tuturan dalam interaksi OP sehari-hari. Tipe tuturan tersebut meliputi tipe deklaratif, representatif, ekspresif, direktif, dan komisif. Adapun tipe yang dominan digunakan yaitu tipe representatif dan ekspresif.

\section{Tipe Deklaratif}

Tindak ilokusi tipe deklaratif, yaitu jenis tindakan yang dapat mengubah suatu keadaan melalui tuturan. Ketika pengambilan data, OP merupakan seorang ketua bidang di suatu organisasi tingkat universitas. Dengan adanya jabatan OP tersebut, maka tindak ilokusi tipe 
deklaratif berpeluang muncul dalam tuturan.

\section{Data 1.}

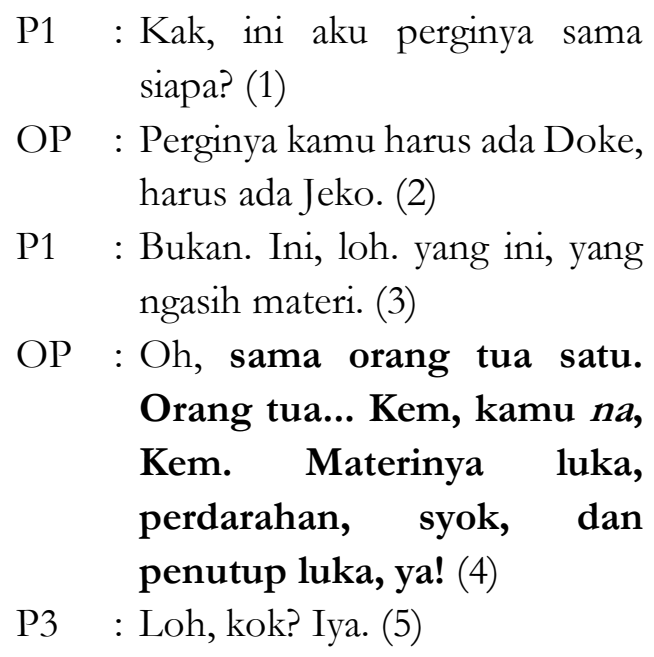

Tindak tutur tersebut terjadi pada tanggal 29 Oktober 2017 di ruang sekretariat organisasi. P1 merupakan anggota organisasi. P1 meminta kepastian OP sebagai ketua bidang perihal keberangkatannya menyampaikan materi. Dalam organisasi tersebut, OP membuat aturan, bahwa jika anggota muda menyampaikan materi harus didampingi anggota senior. Saat itu, OP masih belum menemukan senior yang bersedia. P3 yang merupakan anggota senior langsung ditunjuk OP untuk ikut menyampaikan materi di ekstrakurikuler PMR Wira.

Pada tuturan (4), OP berusaha menggunakan jabatannya sebagai ketua bidang untuk memberi keputusan. Pada tuturan "Sama orang tua satu." OP menggunakan wewenang jabatannya untuk memberikan keputusan kepada P1 bahwa keberangkatannya bersama seorang senior. Pada tuturan "Orang tua... Kem, kamu na, Kem." OP memerintahkan P3 sebagai anggota senior untuk turut menyampaikan materi. Tuturan tersebut hadir untuk membahas urusan organisasi, namun OP menggunakan kalimat tidak formal, yaitu diksi na sebagai kata perintah. Selanjutnya, OP memperjelas perintah pada kalimat "Materinya luka, perdarahan, syok, dan penutup luka, ya!" Penjelasan tersebut bersifat mutlak sehingga P3 tidak memiliki kuasa untuk mengubahnya. Dengan adanya wewenang yang dimiliki OP, maka tuturan tersebut termasuk tindak ilokusi tipe deklaratif.

Tindak ilokusi pada tuturan (4) merupakan jenis kalimat langsung dan literal. Kalimat langsung dan literal, yaitu tindak tutur yang memiliki maksud sama dengan makna kalimat serta tuturan sesuai dengan modus kalimat penutur. OP menggunakan modus kalimat perintahpada kata na-untuk menunjuk P3 menjadi pemateri bersama P1. Selain itu, makna kalimat tersebut juga sesuai dengan maksud, yaitu P3 ditunjuk untuk menyampaikan materi tentang luka, perdarahan, syok, dan penutup luka.

\section{Tipe Representatif}

Tindak ilokusi tipe representatif, yaitu tindak tutur menyatakan sesuatu yang diyakini penutur.

\section{a. Tindak Ilokusi Tipe Representatif Mengeluh}

Data 2.

P1 : Mbak itu cari tikus apa sih?

OP : Dia itu Galur murni. Galur Mistar. Memang susah nyarinya.

P3 : Kayaknya kamu harus usaha itu deh, Rep.

OP : Kadak. Terlalu banyak hak-hak yang harus aku penuhi.

P3 : Bahasamu...

OP : Ya, iya lah. Makhluk hidup, men. (1)

P3 : Makanya belajar dulu. Kali aja dari situ kamu bisa dewasa nanti. (2)

OP : Makanya aku enggak berani kalau pelihara hewan. Terlalu berharga hidupku buat ngerawat itu. Aku aja enggak dirawat. (3) 
Tindak tutur Data 2 di atas terjadi pada tanggal 4 Maret 2018 di Gazebo ketika sedang mengerjakan tugas bersama. Anggota tutur dalam tuturan tersebut melibatkan tiga orang. OP sebagai penutur bertanya tempat penjualan tikus galur murni untuk bahan praktikum kepada P2. P3 yang tidak memiliki pengetahuan tentang itu mencoba mengusulkan ide agar OP membuat bisnis tikus galur murni. Akan tetapi, OP menolak secara tegas usulan tersebut. Lalu, P3 mencoba mengarahkan pembicaraan ke hal lain yang lebih bersifat pribadi.

Tuturan (3) pada Data 2 di atas merupakan bentuk tindak verbal tipe representatif untuk menyatakan keluhan. Tuturan OP merupakan informasi di luar topik pembicaraan untuk menekankan tentang kondisinya. Pada tuturan "Terlalu berbarga bidupku buat ngerawat itu." OP menegaskan alasannya tidak ingin memelihara hewan. Sedangkan pada kalimat keluhan "Aku aja enggak dirawat." OP berusaha menggambarkan kondisi yang sedang dialami. Tuturan tersebut memiliki maksud meyakinkan kepada P3 bahwa dirinya kurang mendapatkan perhatian dari orang terdekat di luar anggota tutur.

\section{b. Tindak Ilokusi Tipe Representatif Berpendapat}

Data 3.

P1 : Mereka juga sudah rencanakan Minggu lalu. Kan, sudah ada niat untuk mereka nyoba, cuma hujan. Enggak bisa, gitu na. (1)

\section{OP : Kalau jogging track, saya rasa bisa, Kak. Apalagi push up, sit up, back up, itu bisa.. Ya Allah, itu cuma butuh tempat aja. Saya rasa bisa, Kak. (2)}

Tindak tutur tersebut terjadi pada tanggal 13 Desember 2017 di ruang sekretariat organisasi saat rapat kepanitiaan. Dalam rapat tersebut terjadi perdebatan antarsenior, sedangkan anggota muda atau panitia hanya menyimak. OP sebagai petutur merasa diperlakukan tidak adil dengan usulan P1 yang dinilai terlalu memanjakan panitia. Oleh karena itu, OP menyampaikan pendapat untuk mematahkan pernyataan P1.

Tuturan OP merupakan bentuk tindak verbal tipe representatif untuk menyampaikan pendapat. OP menyampaikan pendapat yang berlawanan dengan P1. OP tidak setuju dengan sikap P1 yang menurutnya terlalu berlebihan memaklumi keputusan panitia untuk tidak melaksanakan uji coba. Pendapat OP pada tuturan (2) disampaikan dengan menggunakan kalimat langsung, yaitu saya rasa. Pada kalimat "Kalau jogging track, saya rasa bisa, Kak. Apalagi push up, sit up, back up, itu bisa. Ya Allah itu cuma butub tempat aja." OP berusaha meyakinkan seluruh peserta tutur agar setuju dengan pendapatnya yang berdasar pengalaman sebagai panitia. OP menyatakan bahwa persoalan hujan bukan suatu penghalang untuk melaksanakan uji coba tersebut. Adapun pengulangan klausa saya rasa bisa di akhir tuturan, OP memiliki maksud untuk memberikan penegasan terhadap pendapatnya.

\section{c. Tindak Ilokusi Tipe Representatif Menyatakan Fakta}

\section{Data 4.}

OP : Apalagi tuh, Turik itu iya-iya aja tapi ndak dijalankan juga. (1)

P4 : Dia itu ngerjain tapi enggak mau ditekan-tekan, enggak mau ditagih-tagih. (2)

P1 : Turik itu selalu minta bantuan saya kalau ngerjain apa-apa. Dia selalu cerita ke saya kalau ada apa-apa. Jangan su'udzon. (3)

P3 : Tuh, jangan su'udzon. (4) 


\section{OP : Ya, kan aku enggak... itu yang kulihat, ya. Bukan su'udzon. Ya, itu yang kulihat. Itu yang kurasakan. Kalau enggak, ya alhamdulillah. (5)}

Tindak tutur tersebut terjadi pada tanggal 6 Maret 2018 ketika pendapat OP tidak mendapat persetujuan oleh seluruh anggota tutur. P1 sebagai penutur menyampaikan bantahan terhadap pendapat OP sebelumnya, sedangkan P3 sebagai mitra tutur yang sependapat dengan P1 turut mempertegas tuturan P1. Dalam kondisi terjepit dua lawan satu, akhirnya OP menyatakan fakta yang diyakininya sebagai bentuk pembelaan.

Tindak ilokusi pada tuturan (5) merupakan tuturan sebagai bentuk tindak verbal tipe representatif untuk menyatakan fakta. Pada tuturan "...ituyang kulihat, ya. bukan su'udzon. $Y$ a, itu yang kulihat. Itu yang kurasakan." OP berusaha meyakinkan anggota tutur terhadap fakta yang diyakini. Diksi kurasakan dan kuliat, menunjukkan bahwa yang dituturkan merupakan suatu fakta hasil pengamatan, bukan hasil perkiraan. Selanjutnya pada frasa bukan su'udzon, OP menegaskan bahwa dia tidak berprasangka buruk, melainkan hanya menyimpulkan hasil pengamatannya. Selain itu, pernyataan tersebut disampaikan dengan intonasi tinggi untuk melindungi diri. Lalu terakhir, OP kembali menyatakan penerimaan menggunakan kata alhamdulillah yang disampaikan dengan intonasi rendah untuk mengakhiri perdebatan.

\section{d. Tindak Ilokusi Tipe Representatif Melaporkan}

Data 5.

P1 : Aku sudah minta sama Julik. Terus, dia nunggu kamu. Dia enggak tahu berapa uangnya. (1)

\section{OP : Loh, aku sudah kasih catatannya ke dia. (2)}

Tindak tutur tersebut terjadi pada tanggal 29 Oktober 2017 di ruang sekretariat organisasi. P1 sebagai penutur menyampaikan hasil pertemuannya dengan bendahara untuk memproses honor pemateri. P1 merasa kebingungan dengan sistem penerimaan honor. OP sebagai petutur yang merupakan kepala bidang menjelaskan bahwa semua pemasukan telah diserahkan ke bendahara.

Tuturan (2) yang disampaikan OP merupakan bentuk tindak verbal tipe representatif untuk melaporkan. Pada kalimat "Loh, aku sudah kasih catatannya ke dia." OP berusaha meyakinkan P1 bahwa dia tidak salah mengarahkan untuk meminta honor ke bendahara. Tuturan OP disampaikan dengan intonasi tinggi sebagai upaya mempertegas laporan bahwa urusan pembagian honor bukan tanggung jawabnya. Penegasan tersebut terlihat pada penggunaan kata sudah sebagai bentuk kalimat langsung untuk melaporkan.

\section{Tipe Ekspresif}

Tindak ilokusi tipe ekspresif, yaitu tindak tutur yang menyatakan sesuatu secara psikologis oleh penutur.

\section{a. Tindak Ilokusi Tipe Ekspresif Menuduh}

Data 6.

P1 : Kamu itu terlalu cantik, makanya hidupnya harus di hutan aja. (1)

P2 : Iya nanti kalau kamu sekali dandan, haduh. Susah itu. (2)

OP : Maksudnya? (3)

P1 : Kita ini lagi muji kamu, tahu... (4)

OP : Muji kah ngolok? (5)

P1 : Astaghfirullah hal adzim.. (6) 
Tindak tutur tersebut terjadi pada tanggal 6 Maret 2018 ketika sedang membahas tentang jenis pekerjaan bersama dua anggota tutur. OP memiliki latar pendidikan Ilmu Pengetahuan Alam. Dia sangat menyukai pekerjaan yang berhubungan langsung dengan alam. Salah satu pekerjaan yang sedang diminati, yaitu observasi hutan dan orang utan. P1 sebagai penutur sangat mendukung hal tersebut dengan alasan jika selain pekerjaan itu, OP akan diharuskan berpenampilan menarik. Tuturan P1 dipertegas oleh P2 bahwa jika OP bersolek, maka akan menarik perhatian laki-laki. Namun karena OP tidak memahami arah pembicaraan tersebut sehingga menuduh P1 dan P2 sedang meledek.

Tuturan (5) merupakan tuturan sebagai bentuk tindak verbal tipe ekspresif untuk menuduh P1 dan P2. Pada kalimat "Muji kab ngolok?" OP menyatakan perasaan tidak nyaman terhadap tuturan P1 dan P2. Tindak ilokusi tersebut menggunakan tuturan literal dan tidak langsung. Tuturan literal dan tidak langsung, yaitu tindak tutur yang memiliki maksud sama dengan makna kalimat namun tuturan penutur berbeda dari modus kalimat. Pada tuturan tersebut, OP bermaksud menuduh P1 dan P2 sedang mengejeknya. Sedangkan cara penyampaian tuturan tersebut menggunakan struktur kalimat interogatif sehingga menyebabkan P1 dan P2 harus mengklarifikasi.

\section{b. Tindak Ilokusi Tipe Ekspresif Kesal}

Data 7.

P1 : Itu sudah dikjut terakhir. Habis itu sudah enggak ada lagi karena bentrokan semua sama dengan jaga medis di berbagai macam tempat. (1)

\author{
OP : Terus aku tub bingung, jadi \\ solusinya kalau kek gitu terus \\ gimana sih? Aku tuh jengkel.
} (2)

P1 : Ya, banyakin SDM (3)

OP : Aku tuh jeng... aku tuh, ih... aku tuh jengkel. Kalau dibanyakin SDM juga ndak imbang, enggak adil dapat materinya nanti. Emm, aku tuh bingung tahu dari kemaren. (4)

Tindak tutur tersebut terjadi pada tanggal 29 Oktober 2017 ketika P1 dan OP sedang diskusi tentang permasalahan di organisasi. P1 sebagai penutur menyampaikan bahwa kegiatan Dikjut terhenti karena ada kegiatan penting dari bidang lain. Dikjut adalah nama kegiatan yang bertujuan untuk mengulas materi Pertolongan Pertama secara mendalam. OP sebagai kepala bidang merasa kesal dengan kondisi tersebut. Hampir setiap bulan, rancangan kegiatan OP selalu terkendala dengan jumlah anggota dan kesibukan dari kegiatan dari bidang lain.

Tuturan (2) dan (4) merupakan tuturan sebagai bentuk tindak verbal tipe ekspresif untuk menunjukkan rasa kesal. OP menunjukkan rasa kesal dengan menggunakan kata jengkel. Maksud tuturan OP, yaitu agar P1 dapat ikut merasakan perasaannya. Tindak ilokusi yang dilakukan OP termasuk tuturan langsung, yaitu tuturan yang sesuai dengan modus kalimat. Pada tuturan (2) "Aku tuh jengkel." OP menggunakan struktur kalimat deklaratif untuk menyampaikan rasa kesal. Perasaan tersebut kembali ditekankan pada tuturan (4) "Aku tuh jeng... aku tuh, ih... aku tuh jengkel." Tuturan ekspresif tersebut terjadi ketika OP tidak menemukan solusi yang tepat. Rasa kesal tersebut semakin meningkat pada kata seru ih. Tuturan (2) dan (4) dituturkan OP dengan menggunakan intonasi tinggi sebagai bentuk penegasan terhadap kondisi psikologinya. 


\section{c. Tindak Ilokusi Tipe Ekspresif Mengecam}

Data 8.

P1 : Kan kelemahan laki-laki itu di harta, tahta, dan wanita. (1)

OP : Tapi dia kan paham agama. Harusnya mereka paham gitu na kalau itu enggak boleh. 'Halah, emangnya kalau kamu yang ngalami, kamu bisa, Rep? Omong doing.' (2)

Tindak tutur tersebut terjadi pada tanggal 29 Maret 2018 ketika OP menanggapi penjelasan P1 dengan cepat. OP menanggapi penjelasan P1 dengan berpedoman pada prinsip kelogisan yang diyakini. Menyadari tanggapannya tersebut, OP kembali memberikan tanggapan yang terpusat kepada diri sendiri.

Tindak ilokusi pada tuturan (2) merupakan tuturan sebagai bentuk tindak verbal tipe ekspresif untuk mengecam. Tuturan OP pada tuturan (2) bermaksud memengaruhi P1 agar turut merasakan situasi psikologinya. Ketika bertutur, OP menggunakan tuturan tidak langsung berbentuk interogatif, yaitu pada tuturan "balah, emangnya kalau kamu yang ngalami, kamu bisa, Rep?" Meskipun tuturan tersebut berupa kalimat tanya, namun maksud dari kalimat tersebut untuk meremehkan. Hal tersebut dipertegas dengan kata kecaman omong doang yang sepadan dengan arti kata omong kosong. Pada tuturan tersebut OP mengecam diri sendiri karena terlalu mudah menilai tanpa melihat kemampuan diri sendiri.

\section{Tipe Direktif}

Tindak ilokusi tipe direktif, yaitu tindak tutur yang digunakan penutur untuk menyuruh lawan tutur melakukan sesuatu.

\section{a. Tindak Ilokusi Tipe Direktif Memerintah}

Data 9.

OP : Jangan diam aja na, Kem. (1)

P2 : Aku enggak tahu mesti ngapain. (2)

OP : Ambilkan papan scanner di tasku. (3)

P2 : Iya. (4)

OP : Catat di bettle, pre pupa, instar 2. (5)

Data 10.

OP : Kamu catat sama bantui foto ya. (1)

P2 : He'em. (2)

OP : Kem, foto! (3)

Data 11.

OP : Kem, ambil tempat lagi satu yang daging! (1)

P2 : Ih, bau. Nggak mau (2)

Data (9) terjadi pada tanggal 17 Maret 2018 sedangkan data (10) dan (11) terjadi pada tanggal 24 Maret 2018. Ketiga tuturan tersebut terjadi ketika OP sebagai penutur sedang melakukan penelitian bersama P2. Data (9) terjadi pada minggu pertama. P2 merupakan mahasiswa Ilmu Sosial. Oleh sebab itu, P2 hanya memainkan telepon genggam selama penelitian karena tidak tahu tugas yang dapat dibantu. Selanjutnya, data (10) dan (11) terjadi pada minggu kedua. Pada data tersebut, P2 telah memiliki sedikit pengetahuan dari pengalaman di minggu sebelumnya.

Data tindak tutur (9), (10), dan (11) merupakan tuturan sebagai bentuk tindak tutur tipe direktif untuk memerintah. Tuturan OP merupakan suatu strategi untuk mewujudkan keinginannya terhadap P2 sebagai lawan tutur. Data tindak tutur 
(9), tepatnya pada tuturan (1), OP memerintah P2 untuk membantu menyelesaikan penelitiannya dengan menggunakan tuturan tidak literal dan langsung. Tuturan tidak literal dan langsung, yaitu tindak tutur yang memiliki maksud lain dengan makna kalimat namun tuturan sesuai dengan modus kalimat. Tuturan "Jangan diam aja na, Kem!" merupakan kalimat imperatif berbentuk larangan agar P2 tidak hanya sekedar diam. Namun saat kalimat tersebut dituturkan, P2 tidak sungguh-sungguh diam tetapi sedang memainkan telepon genggam. Dengan demikian, maksud dari tuturan OP, yaitu memerintah P2 untuk membantu penelitiannya. Keinginan OP tersebut dituturkan secara langsung pada tuturan (3) dan (5).

Pada data tindak tutur (10) dan (11), OP menuturkan tindak tutur direktif secara literal dan langsung. Tindak tutur literal dan langsung, yaitu tindak tutur yang memiliki maksud sama dengan makna kalimat serta tuturan sesuai dengan modus kalimat. Pada tuturan tersebut, OP menggunakan struktur kalimat imperatif untuk memerintah P2. Pada tuturan (10) "Kamu catat sama bantui foto ya!" OP memerintah P2 untuk mencatat penemuannya dan mendokumentasikan bentuknya, sedangkan pada tuturan "Kem, foto!” OP memerintah P2 untuk segera mengambil gambar. Hal tersebut juga berlaku pada data tindak tutur (11) tuturan (1). Pada tuturan "Kem, ambil tempat lagi satu yang daging!" OP memerintah P2 untuk mengambilkan satu gelas plastik berisi daging.

\section{b. Tindak Ilokusi Tipe Direktif Menuntut}

Data 12.

OP : Badiklat itu di mana, sih? (1)

P2 : Situ na. (2)

OP : Aku tau Badiklat itu di sebrang. Coba kamu itu jangan

\section{kebiasaan kalau ditanyai tempat itu! (3)}

Data (12) terjadi pada tanggal 23 Mei 2017 ketika OP sebagai penutur bertanya alamat Badiklat. P2 merupakan petutur yang akan melakukan latihan semimiliter di tempat tersebut. P2 menjawab pertanyaan OP dengan penjelasan singkat sambil menunjuk arah Samarinda Seberang. OP merasa jawaban tersebut tidak memuaskan pertanyaannya. Oleh karena itu, dia menuntut P2 agar memberikan penjelasan yang lebih lengkap.

Tindak ilokusi OP pada tuturan (3) merupakan tuturan sebagai bentuk tindak verbal tipe direktif untuk menuntut penjelasan. Pada tuturan tersebut, OP berusaha memengaruhi lawan tutur agar bersedia melaksanakan keinginannya. Tuturan OP tergolong tindak verbal karena tuntutan yang diinginkan berupa penjelasan berupa kata-kata, bukan tindakan atau aksi. Tuturan (3) termasuk tuturan tidak literal dan langsung, yaitu tindak tutur yang memiliki maksud lain dari makna kalimat namun tuturan sesuai dengan modus kalimat. Pada tuturan "Coba kamu itu jangan kebiasaan kalau ditanyai tempat itu!" OP menggunakan struktur kalimat imperatif untuk melarang. Sedangkan maksud dari tuturan tersebut, yaitu OP meminta P2 untuk memberikan penjelasan yang lebih detail tentang alamat Badiklat.

\section{Tipe Komisif}

Tindak ilokusi tipe komisif, yaitu tindak tutur yang menyebabkan penutur terikat untuk melakukan suatu tindakan di masa mendatang.

\section{a. Tindak Ilokusi Tipe Komisif Menolak}

Data 13.

P1 : Coba naruhnya bagus-bagus. (1) 


\section{OP : Kenapa juga? Kan, memang sudah berantakan kek gitu.}

(2)

P1 : Ya, setidaknya kamu enggak nambah berantakin. (3)

OP : Emang ada aturannya, ya? Yang penting kan sudah kukembalikan. (4)

Tindak tutur tersebut terjadi pada tanggal 6 Mei 2017 di SMA Negeri. Tuturan terjadi ketika OP bersama P1 usai melatih anggota ekstrakurikuler PMR. Saat itu, OP sedang mengembalikan daftar hadir ke bagian Tata Usaha (TU). P1 sebagai penutur menegur OP yang menaruh daftar hadir secara asal. Akhirnya, P1 menyuruh OP untuk merapikan berkasnya, namun P1 tidak melaksanakan dan malah meminta penjelasan.

Tuturan (2) dan (4) merupakan tuturan sebagai bentuk tindak tutur tipe komisif untuk menolak. OP berusaha menyesuaikan kondisi sesuai keinginannya dengan menolak tuturan P1. Tuturan (2) dan (4) tergolong tuturan literal dan tidak langsung, yaitu tindak tutur yang memiliki maksud sama dengan makna kalimat namun tuturannya berbeda dari modus kalimat. Pada tuturan "Kenapa juga? Kan, memang sudah berantakan kek gitu." OP menggunakan struktur kalimat interogatif untuk menolak perintah P1. OP menolak perintah dengan alasan jika berkas-berkas di TU memang berantakan sejak awal. Begitu pula pada tuturan (4), OP menolak penjelasan P1 dengan menggunakan kalimat interogatif "Emang ada aturannya, ya?" Selanjutnya, OP kembali menyampaikan alasan untuk membela diri dengan mengatakan "Yang penting kan sudah kukembalikan." Penggunaan kalimat interogatif tersebut menyebabkan P1 harus memberikan penjelasan agar OP melaksanakan perintahnya.

\section{b. Tindak Ilokusi Tipe Komisif Bersumpah}

Data 14.
P3 : Mbak Tarep sih ngomong nyaring-nyaring, kayak enggak ada kontrol aja volume. (1)
OP : Mana ada. Sumpah, ya... fitnah. Kalau ini fitnah. (2)
P3 : Kalian juga bahas keke gitu di depan ruangannya. (3)

Tindak tutur tersebut terjadi pada tanggal 8 Desember 2017 di sekretariat organisasi. OP dan P3 ketika itu sedang menceritakan hasil pertemuan dengan pembina. Saat itu, OP menjabat sebagai DPO sedangkan P1 sebagai ketua umum. Pertemuan tersebut bertujuan untuk memperkenalkan pengurus baru. Namun ketika penyambutan, OP dan P1 merasa sikap pembina tampak tidak ramah seperti sebelumnya. Perubahan sikap pembina tersebut lalu didiskusikan bersama P1 dengan menceritakan kronologi secara lengkap.

Tuturan (2) merupakan tuturan sebagai bentuk tindak verbal tipe komisif untuk menyatakan sumpah. OP menyatakan kesaksian tekad bahwa dia tidak melakukan kesalahan sebagaimana yang dikatakan P3. Tuturan "Mana ada. Sumpah, ya... fitnah. Kalau ini fitnah." tergolong pada tuturan literal dan langsung. Tuturan literal dan langsung, yaitu tindak tutur yang memiliki maksud sama dengan makna kalimat serta tuturan penutur sesuai dengan modus kalimat. OP menyatakan kesaksian secara langsung dengan menggunakan kata sumpah untuk melepas tuduhan P3.

\section{E. PENUTUP}

Berdasarkan hasil dan pembahasan yang telah dijabarkan sebelumnya, maka dapat disimpulkan bahwa terdapat lima tipe tuturan yang digunakan OP dalam berinteraksi sehari-hari. Tipe tuturan tersebut, yaitu (a) tipe deklaratif untuk 
memberi keputusan; (b) tipe representatif dengan maksud mengeluh, berpendapat, menyatakan fakta, dan melaporkan; (c) tipe ekspresif dengan maksud menuduh, mengekspresikan rasa kesal, dan mengecam; (d) tipe direktif dengan maksud memerintah dan menuntut; dan (e) tipe komisif dengan maksud menolak dan bersumpah. Adapun bentuk tuturan yang digunakan OP dominan menggunakan kalimat langsung dan literal.

\section{DAFTAR PUSTAKA}

Al-Mahfani, M. K. (2009). Dabsyatnya Doa Anak Yatim: Mengungkapkan Rabasia Keberkahan Menyantuni Anak Yatim. Jakarta: Wahyu Media.

Ali, M., \& Asrori, M. (2016). Psikologi Remaja: Perkembangan Peserta Didik. Jakarta: Bumi Aksara.

Chaer, A. (2010). Kesantunan Berbahasa. Jakarta: Rineka Cipta.

Dardjowidjojo, S. (2014). Psikolinguistik: Pengantar Pemahaman Bahasa Manusia (Kedua). Jakarta: Yayasan Pustaka Obor Indonesia.
Leech, G. (2015). Prinsip-Prinsip Pragmatik. Jakarta: Penerbit Universitas Indonesia (UI-Press).

Martadillah. (2007). Pengembangan Diri. Balikpapan: Akademi Akuntansi Balikpapan Press.

Mulawarman, W., \& Iswanto, Y. (2018). Penerapan Teknik Bagi Unsur Langsung (BUL) pada Identifikasi Afiks Bahasa Dayak Benuaq. DIGLOSIA: Jurnal Kajian Bahasa, Sastra, Dan Pengajarannya, 1(1), 13-18.

Nadar, F. X. (2013). Pragmatik dan Penelitian Pragmatik. Yogyakarta: Graha Ilmu.

Napitupulu, C. A. (2009). Resiliensi Remaja Yatim Piatu di Panti Asuban Mardi Siwi Kalasan Yogyakarta. Universitas Sanata Dharma, Yogyakarta.

Yule, G. (2014). Pragmatik. Yogyakarta: Pustaka Pelajar. 
